\title{
J
}

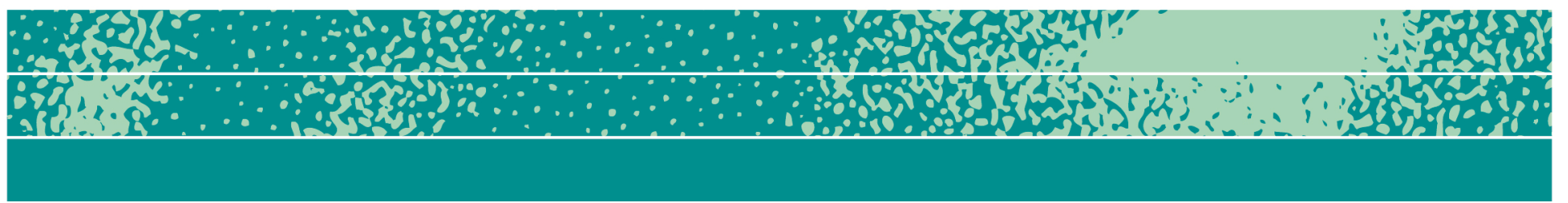

\section{Entrepreneurship: A Challenging, Fruitful Domain for Ethnography}

Elizabeth K. Briody and Alex Stewart

\section{Background to the Themed Articles}

A group of senior scholars, led by Derek Lidow, planned and convened a global conference called Expanding Understanding of Business Creation: Adding More Ethnography into the Research Mix, held at Princeton University, August 1-3, 2017. Sponsored by the Ewing Marion Kauffman Foundation and Princeton University's Keller Center, the conference sought to

bring together anthropologists, sociologists, and entrepreneurship researchers with funding agencies to discuss how best to stimulate and support new research to collect and analyze detailed observations and information on how start-up teams react to and implement new firms in real time (https://www.princetonkauffman2017.com/about, accessed October 6, 2019).

The conference was predicated on the concept that formal interviews and administrative databases typically used by entrepreneurship researchers could not furnish in-depth detail on team dynamics and business interactions that could be derived from ethnographic methods. Bringing researchers from multiple disciplines together to share views and insights had the potential to lead to future
Page 1 of 26

JBA 8(2): 141-166

Autumn 2019

(C) The Author(s) 2019 ISSN 2245-4217

www.cbs.dk/jba 
research collaborations. Lidow's (2017) article in the Journal of Business Anthropology underscores these motivations.

Both of us (Stewart and Briody) were members of the organizing committee. Stewart moderated a session on the use value of ethnography while Briody's session focused on entrepreneurship done ethnographically. Other sessions emphasized risks and opportunities for employing observational data, mixed methods approaches, and foundation and agency perspectives on ethnographic studies in entrepreneurship, among others. Five of the six papers published among these themed articles were presented at the conference, with a sixth included at a later date. Our introductory article for these themed papers 1) explores key literature and methodological approaches used in entrepreneurship studies by anthropologists, 2) provides an overview of each of the articles, 3) identifies emerging patterns about both the researchers and their study participants in context, and 4) advocates for the value of understanding entrepreneurship in context.

\section{Anthropological Studies and Methods in Entrepreneurial Research}

Anthropological writings on entrepreneurship and family firms have focused on "small-scale societies with distinctive traditions and values" (Rosa and Caulkins, 2013, p. 98). There are exceptions, such as Yanagisako (2002). Anthropological writings_-again, with exceptions (Marcus and Hall, 1991) - have also focused on small enterprises, as we see from the surveys by Stewart $(1990 ; 1991 ; 2003 ; 2014)$. The literature is rich with examples at collective levels, such as ethnic diasporas (Oxfeld, 1993), indigenous arts businesses (Meisch, 2002), industry clusters (Blim, 1990; Yanagisako, 2002), and established family firms (Kondo, 1990). Rosa and Caulkins (2013, p. 101) argue that these writings advance "themes... that could profitably be developed further by entrepreneurship researchers."

Nevertheless, largely missing in the corpus of anthropological works is research at the level of new ventures. Here are two demonstrations. First, Appendix A lists 100 recent doctoral dissertations on entrepreneurship, using the modal anthropological method of ethnography. (Of the 100, 32 are in anthropology, 15 in sociology, and one in ethnomusicology.) Only three of these dissertations-two in anthropology - focus as their unit of observation or analysis on one or more new ventures. Second, the Human Relations Area Files (HRAF) is a massive index at the paragraph level of more than 600,000 pages of ethnographic materials (Ember and Ember, 2009;

http://ehrafworldcultures.yale.edu/ehrafe/; see Brettell, 2009, for reasons it is not currently in fashion). We can find only one HRAF-based publication on entrepreneurship (Caulkins and Peters, 2002), and its units of analysis are ethnic groups. 
Perhaps the reason for these lacunae is anthropologists' hostility to business (Stewart and Aldrich, 2015). Nevertheless, anthropological studies of organizations are extensive, as demonstrated by the overviews by Jordan and Caulkins (2013), Wright (1994), and Zickar and Carter (2010). These studies offer unique insights into the worlds of organizational strategists - meaning, all organizational actors in their various contexts. For example, Riles' work (2011) on back-office lawyers in global derivatives trading exemplifies a point made by Smith (2001: 220 ) that these ethnographies show "how routine jobs are complex and complex jobs are routine." Anthropologists also have provided managerial prescriptions based on field research (Briody, Trotter, R. T. and Meerwarth, 2010; Chapple and Sayles, 1961), though the focus is not explicitly on entrepreneurship.

Good ethnography in organizations reveals actors who manage, with varying success, the contradictions and ambiguities of their work. Such observations are diacritical markers between genuine ethnography and the "qualitative" studies found more commonly in business school writings. Search through the former and you will find variants of words like "disparage," "mistake," "confusion," "contradiction," "blame," "ambiguity," "bias," mislead," "pretend," "conflict," and "anger." Search through the latter and all will seem fine; these terms will be few and far between. The reason for the difference lies in the ethnographic approach.

How do ethnographers succeed in recording what we all must know goes on in any human setting? One answer is found in Table 1 on ethnographic "criteria, challenges, and tactics" (adapted from Stewart 1998: 17). "Criteria" refer to epistemic values appropriate to ethnography, "challenges" to the main limitations on success in these terms, and "tactics" to the choices fieldworkers can make to overcome the limitations so far as possible. Four tactics are particularly germane for our concern with entrepreneurship research. Two tactics concern how ethnographers act: they "search for disconfirming observations" (Veracity tactic 2) and they "explore... doggedly rooting out what interests them" (Perspicacity tactic 2, 1988: 57). 
Table 1: Expectations for Ethnographic Method: Criteria, Challenges, and Tactics*

\begin{tabular}{|c|c|c|c|}
\hline Epistemic Value & Veracity & Objectivity & Perspicacity \\
\hline $\begin{array}{l}\text { Conventional } \\
\text { equivalent }\end{array}$ & $\begin{array}{l}\text { validity (excluding } \\
\text { external validity) }\end{array}$ & $\begin{array}{l}\text { reliability } \\
\text { (excluding } \\
\text { consistency) }\end{array}$ & $\begin{array}{l}\text { generalizability, } \\
\text { external validity }\end{array}$ \\
\hline $\begin{array}{l}\text { Underlying } \\
\text { question }\end{array}$ & $\begin{array}{l}\text { verisimilitude of } \\
\text { depiction }\end{array}$ & $\begin{array}{l}\text { transcendence of } \\
\text { perspectives }\end{array}$ & $\begin{array}{l}\text { applicability of } \\
\text { insights elsewhere }\end{array}$ \\
\hline $\begin{array}{l}\text { Research } \\
\text { process } \\
\text { challenges }\end{array}$ & $\begin{array}{l}\text { limits to learning } \\
\text { due to conditions in } \\
\text { the field or to } \\
\text { researcher's role or } \\
\text { personal limits }\end{array}$ & $\begin{array}{l}\text { sensitivity of } \\
\text { results to context; } \\
\text { risk of reactivity; } \\
\text { lack of fully } \\
\text { specifiable } \\
\text { research context; } \\
\text { unknown context } \\
\text { findings linkages }\end{array}$ & $\begin{array}{l}\text { method cannot } \\
\text { create insights; } \\
\text { invalid or missing } \\
\text { taxonomies limit } \\
\text { knowledge of } \\
\text { where an insight } \\
\text { can "travel" }\end{array}$ \\
\hline $\begin{array}{l}\text { Related research } \\
\text { coping tactics } \\
\text { (bolded if } \\
\text { crucial; struck } \\
\text { through if } \\
\text { questionable) }\end{array}$ & $\begin{array}{l}\text { prolonged } \\
\text { fieldwork; search } \\
\text { for disconfirming } \\
\text { observations; good } \\
\text { participative role } \\
\text { relationships; } \\
\text { attention to } \\
\text { context; multiple } \\
\text { modes of data } \\
\text { collection }\end{array}$ & $\begin{array}{l}\text { trail of } \\
\text { ethnographer's } \\
\text { path; respondent } \\
\text { validation; } \\
\text { feedback from } \\
\text { outsiders; } \\
\text { interrater checks } \\
\text { on indexing; } \\
\text { comprehensive } \\
\text { data archive }\end{array}$ & $\begin{array}{l}\text { intense } \\
\text { consideration of } \\
\text { the data; } \\
\text { exploration }\end{array}$ \\
\hline
\end{tabular}

*Source: Table 2.1 in Stewart (1998: 17) with slight modifications. Used with permission.

All researchers can use these tactics. However, ethnographers employ these tactics distinctively. First, they engage in "prolonged fieldwork," "the single most potent tactic to enhance veracity" and a tactic unknown in most entrepreneurship research (1988: 20). Second, they find, create and develop "good participative role relationships" that enable engagement in a host of social scenes, many of which are restricted to insiders' eyes (1988: 22-26). Myriad examples could demonstrate this latter point. An example in the entrepreneurship research is Rencher's (2012) participation as a contestant in pitch 
competitions. Without this experience, she would have had less awareness of the "embodied" experience and identification with a venture, nor would she have learned how uncertain the rewards were for the winners $(2012: 118,142,175)$.

The methodological approaches that enable insights make ethnography an unlikely candidate for researchers on start-ups. Three reasons come to mind. First, much precedes the visible signs of a start-up (Learned, 1992). Identifying new ventures from near their beginnings is difficult and timing the start of research and negotiating access are challenges. Second, the pre-organizational stage is a time of instability and switches in direction- "pivots" in current parlance. Negotiating access to field sites is always an ongoing process (Feldman, Bell, and Berger, 2003), but it is particularly dynamic for start-ups. Not every founder is enchanted to learn that researchers plan to hang around for months, as active participants. Hence, there is a third problem: finding appropriate roles. The risk of reactivity is easy to exaggerate in research on established organizations, let alone industry clusters and other larger entities. Early stage ventures, however, lack the slack to let scholars hang around. Because they are small, researchers are more intrusive. These ventures are also fragile. For example, founders might worry about their capacity to defend their intellectual property.

One solution is to give up hope for participant observation. Anthropologist use many other methods, such as open-ended interviews that elicit study participant perceptions with minimal researcher influence. Many interview styles can be found in the anthropological literature, as Strathern (2012) observes about the chapters in Skinner (2012). All styles, if ethnographic, should minimize the scholar's conceptions and draw out those of the study participants. Spradley's The Ethnographic Interview (1979) remains, regardless of views on its mode of cognitive anthropology, helpful for advice on this score. In our view, ethnographic interviews are useful tools in the anthropologist repertoire. However, in contrast to participant observation, they have two key limitations. The first involve discrepancies between what study participants say they do and what they do if observed (Bernard, Wutich, and Ryan, 2017, p. 28). The second entails discrepancies between what study participants say they did in the past, and the historical record (Golden, 1992).

Recording events in real time, as Lusk and Harrison (2002) did in The Mousedriver Chronicles, overcomes these limitations. They recorded their efforts to recognise and understand obstacles as they arose in their venture. They recorded their efforts to discover who could help them. If they had waited, they would have been hard-pressed to remember just how they came to conceptualize problems, how they settled on people to help, and how well their expectations were met. Their book began as a blog. It is not anthropological. But it represents an approach to 
ethnography that has been used in many contexts: the auto-ethnography. Auto-ethnographers make use of pre-existing social roles, which they did not take up for the sake of research. For example, Hayano (1979) did not become a card-playing gambler so he could study poker players. Learned (1995) did not co-found and lead a software firm to study how firms create resources.

An ethnographer could, of course, take on a "complete" membership role (Adler and Adler, 1987), and launch a venture purely to study the experience-as Rencher did (2012). However, as she also found, her venturing while conducting field research was not as encompassing as full-time venturing in her past. Doing both with the needed intensity is hard to imagine. Nevertheless, we cannot rule it out. Anderson's (2006: 375) definition of "analytic autoethnography" does not do so. "Analytic autoethnography refers to ethnographic work in which the researcher is (1) a full member in the research group or setting, (2) visible as such a member in the researcher's published texts, and (3) committed to an analytic research agenda focused on improving theoretical understandings of broader social phenomenon" (Anderson, 2006: 375). By this third point, he distinguishes a social science stance from a prominent humanistic, interpretive stance represented by, among others, Ellis and Bochner, whose critique of Anderson's article is written in character and, as it happens, disputes the social science/humanities (art) distinction.

We draw attention to the differences between the social sciences and humanities approaches. Should one search for autoethnography in recent writings, one might conclude that it is not suited to realist research but only to "subjective and evocative" writings, quoting Atkinson's (2016) commendation of Anderson (2016). For example, the research for Learned's dissertation, perhaps the earliest auto-ethnography (or "native ethnography," in his parlance), was conducted when was Chairman of the Board but no longer CEO. Data included a massive archival record since both of the founders were, in their words, "recovering accountants;" moreover, Learned's dissertation chair made three site visits. This dissertation is also notable for making use of a resource often found in doctoral programs, at least those in business: extensive entrepreneurial experience by the students. The potential that these experiences provide is demonstrated by the auto-ethnographic studies listed in Appendix B. Four of the 13 auto-ethnographies study new ventures, a rate that is 10 times higher than the rate in non-auto-ethnographic studies in Appendix A.

As we consider these various methodological challenges in using ethnography to conduct studies of entrepreneurship, we should not get too bogged down so that we can't claw ourselves out of a hole. Yes, to understand the life span of an entrepreneurial venture, timing matters. Alignment between an anthropologist's availability during the pre-startup 
phase of entrepreneurial ventures would be ideal. Unfortunately, field researchers, like entrepreneurs, face constraints (e.g., funding, language acquisition, contacts) that affect their access to the field and the people associated with it. Yet, when anthropologists begin an ethnographic project, they typically end up gathering data-sometimes on exactly what they planned to study and sometimes they have to punt! So, it is rare when the planned ideal works out. Let's take a look at what the contributors to these themed articles actually did while in the field. Some interesting patterns emerge that offer clues about conducting field research on entrepreneurs and using that process to help fill out the broader context in which entrepreneurial work occurs.

\section{An Overview of the Six Articles}

We begin with the study by Onomake-McShane since entrepreneurs have been part of Nigerian culture reaching back to pre-Colonial times. Her case study focuses on "Preston," a Nigerian entrepreneur who has embraced global business opportunities by establishing ventures with Chinese counterparts. She emphasizes the value of conducting ethnographic research to help thwart the view that Africans lack agency. She manages to engage in "ethnography by appointment" (Kemmitt 2008) with Preston, as his business schedule permits. Through the conversations, interviews, participant observation, historical and presentday documents, and social media, Onomake-McShane produces an article that will keep you clambering for more.

A fascinating component of her account is her ability to identify and distill the critical elements of Preston's approach to entrepreneurship in his cross-cultural ventures situated in his own country; these attributes are evident in the attitudes and behavior of other entrepreneurs in Onomake-McShane's larger study. First, Preston must rely on his own financial and social capital. Trust and relatedness, beyond kinship networks, are essential in establishing and maintaining rapport, and ultimately his business. Second, and perhaps more striking, is Preston's intuition to manage his own "brand" - that is, structure his interactions with the Chinese so that they perceive him as trustworthy. For example, he conducts business in public so that anyone nearby can observe his transparency; producing an array of gems for sale from which his buyers can select is a critical feature in marketing himself. Onomake-McShane's work emphasizes how entrepreneurs adapt in a global world. While the specifics of their adaptation are a function of time (i.e., era), place (i.e., location), and client group, the long-standing tradition of entrepreneurs is ingrained in the national culture and identity. Thus, her study zooms in on a case but zooms out so that the reader can understand the case within an historical context.

Bolton, Aguirre, and Erickson suggest that entrepreneurship is 
not necessarily confined to individuals but instead, can reflect the collective behavior of a group-in this case, an entire community in the Altiplano of Peru. Like the Nigerians documented by Onomake-McShane, the people of the Altiplano have relied on entrepreneurial ventures as an important income-generating strategy. Community entrepreneurship came into its own in 1963 with the establishment of the Taraco-Chijnaya Project. Supported by a regional public development agency intent on addressing a flood crisis (and covertly, agrarian reform), the project led to the purchase of a hacienda whose land would be held in common. Based on decades of ethnographic research and practice, the authors trace the history of this collective effort through its various combinations of farming, animal husbandry, and cheese production.

An intriguing part of this article is the struggle between the individual and the collective. The agrarian cooperative was put to rest in 1992 as the "individualist ethos" reasserted its presence within the community; the once-communal lands reverted to individual control. However, the collectivity persevered and reaped success in other ways: 1) communal decisions on rotating loans to improve animal husbandry practices, and hence milk production, and 2) the establishment of a cheese factory cooperative which purchased community members' milk daily and employed community members on a rotating basis. While a number of challenges associated with these two efforts have been addressed, several pertaining to the management of the factory and its products remain in a kind of limbo. Thus, just as individual entrepreneurs experience difficulties as their ventures launch, develop, and mature, so too has the community of Chijnaya as it has attempted to reconcile individual and group-based entrepreneurship through its trial and error approach.

Rencher's article introduces us to one U.S. university's survival strategy that is banking on an innovative educational approach involving entrepreneurship. Fearing that its message was no longer resonating with potential students, the institution engaged in organizational-wide change to refocus its mission and offerings. Rencher, who worked for the university in a senior leadership role, helped lead the transformation. Both her participant observation and strong theoretical background enabled her to describe and explain the university's shift to an entrepreneurial focus. Student preparation for entrepreneurial careers would occur through curriculum redesign as well as student creation and management of "for-profit corporations." In essence, its collective approach to entrepreneurship was devised to produce individual entrepreneurs.

Figure 3 from her article furnishes an overview of how the business development process works, complete with a business concept, product and service validation, business plan, "pitch for resources," and actual business operations. Innovative are the "dynamic case studies" tied 
to student businesses. Different stakeholders (e.g., mentors, advisory board, other students) contribute their feedback, contacts, and other resources to a given case study as a way of helping the student refine his/her ideas and decisions pertaining to the nascent business. The university's expectation is that this kind of hands-on training, combined with coursework, will position graduates for the job market. Her study represents a structural response to the higher education marketplace, one that does not simply talk about innovation in the form of enterprising graduates, but actually implements it.

Jackson and Sanyal's qualitative study of Black women business owners in the U.S. digs deep into the challenges of running a business venture given their gender and racial identities. The authors skillfully describe the stereotypical views these women confront from society at large: they work in hair salons, they have "bad attitudes," they are intimidating - the list goes on. In a strategy reminiscent of entrepreneurial "brand management" (Onomake-McShane, this issue), these women focus on "impression management" to counteract such perspectives. They work to present themselves as professionals and their businesses as operating with the highest of standards. Some remove identifiable attributes associated with the Black community from their marketing and advertisements.

Simultaneously, these entrepreneurs have to steer their businesses toward success as part of the Black community. Some of their clients seek special favors (e.g., delayed payments), in an attempt to break down the boundary between personal and professional relationships. These women business owners adopt other strategies-seemingly through trial and error-to cope, including specifying the price of the product or service at the start of the interaction or transaction. Thus, they experience and must respond to client-induced stress from multiple quarters on an ongoing basis. Interestingly, the authors prefer not applying the term "entrepreneur" to these business owners because of its stereotypical images (e.g., profitability as sole success measure, a White male domain, necessity of full-time engagement). Their critique points to the narrowness and exclusivity of such popular characterizations.

Sanyal's article assesses a different aspect of entrepreneurshipthe perspective that microcredit can enable women to become entrepreneurs, thereby increasing their earnings, skills, social status, and freedom. Her research, like that of other contributors to these themed articles, emphasizes the "initiative" that her West Bengali entrepreneurial women take to develop their small businesses. Microcredit loans can be life saving for some women; indeed, her narratives reveal an improvement in agency for these women business owners. Because they can borrow against their microcredit group, they are no longer reliant on local moneylenders whose interest charges are exorbitant. Once their loans are repaid, they are eligible to take out additional loans. 
However, from her large sample, only a small proportion of women access the microcredit loans for their own purposes. Sanyal asks why there is such a low incidence of entrepreneurship. It turns out that the entrepreneurial perspective embedded in the non-governmental organizations with whom she worked to secure her sample does not always hold. First, the common practice of women transferring any loans to one's husband or grown sons for their own ventures is a key reason for the low numbers of women entrepreneurs. Second, loans are a necessary but not sufficient condition for success. Certain skills are necessary "to produce marketable goods," skills which women may lack. Finally, Sanyal's narratives show that women become entrepreneurs primarily as a "last resort." She outlines six conditions associated with their choice to secure microcredit, including a "husband's functional absence from household management" or his "paltry earnings." Investigations like Sanyal's get us closer to understanding the relative success of microcredit programs and women entrepreneurs.

Erickson's sequential studies in Brazil for a desktop printer manufacturer reveal entrepreneurial behavior in unexpected places. His ethnographic team stumbled upon a puzzle in an early meeting with their new client: "people were buying printers, but not the ink." The team soon had a possible explanation-that households preferred printing at a shop called a "LAN house" because it was less expensive. These shops neither belonged to a commercial chain nor looked similar in appearance. Moreover, they provided a range of services (e.g., printing, scanning, getting computer help) and were typically located in lower-income areas. Initial client reaction was mixed, with some skepticism that such businesses were important. Nevertheless, the team was allowed to continue its work and did so through home and store interviews and visits to various $L A N$ Houses. Their research confirmed that lower-middleclass households patronized LAN Houses for their printing needs. In addition, visits to LAN Houses and their suppliers revealed the availability of bulk ink and bulk-ink adaptors for printers.

A suggestion by one of the client managers to consider a bulk-ink printer for sale in Brazil became an example of intrapreneurial activity (i.e., entrepreneurship within an organization). A second round of data collection in LAN Houses encompassed a usability trial with new printers and bulk-ink adaptors. The new product was tweaked over time and has been sold throughout Latin America. Erickson makes the case that study participants in all the key roles in the two sequential studies exhibited entrepreneurial behavior: household members, LAN House employees, and client managers. A key take-away from his article is that these disparate "individuals" form a kind of entrepreneurship cluster in response to a product on the market. Households and small LAN House businesses identified workarounds to address the printer's drawbacks while the manufacturer had no idea that its product had created such 
workarounds. In the end, a printer that accommodated bulk ink became the solution of choice.

\section{Emerging Patterns about the People in Context}

In all six cases, the researchers conducted their studies by adjusting to their field conditions. They had to gain access, develop connections, and build rapport with their study participants. They took their cues from them, reproducing their verbatim comments, paraphrasing any notable events and experiences, and/or reflecting on unforeseen actions or decisions in relation to their study participants' worldviews. Indeed, some authors, reliant on their extended association with their study participants (Bolton et al.; Rencher) or on their remarkable notes and video footage (Erickson), fold in forms of "analytic autoethnography" (Anderson 2006: 375) into their articles. In all cases, contradictions and ambiguities surfaced repeatedly in the field; the researchers had to confront them, while also trying to make sense of their significance and implications for their ongoing data collection and preliminary analyses. The researchers, like those they studied, could be understood as entrepreneurs as well; indeed, Erickson makes that argument eloquently citing Schumpeter's (1947: 152) "getting new things done" perspective.

Even when the researchers specifically planned to study aspects of entrepreneurship (Onomake-McShane; Rencher) or small-business startups (Jackson and Sanyal), the researchers focused on the interviewee in context, and not on any particular textbook definition of entrepreneur or entrepreneurship. Consequently, they clearly recognized that their study participants were at different stages in the development of their ventures, with some recently launched and others quite mature; capturing the entrepreneurial venture from the pre-planning phases through its maturity and transition phases was not an issue for them. They viewed their role as learning what they could from their study participants during that period in their study participants' lives. The result: without a pre-conceived notion of entrepreneurship, the researchers were able to examine a wide array of circumstances and conditions surrounding the work of entrepreneurial-minded individuals (Onomake-McShane; Rencher; Jackson and Sanyal; Sanyal; Erickson), households (Bolton et al.; Sanyal; Erickson), and employees (Rencher; Erickson).

Taken together, the six articles break open the mold on entrepreneurship. First, the articles reveal variation in entrepreneurial demographic attributes. They dispel the stereotypical image of an entrepreneur as a "White man standing in front of concept boards delivering a pitch or developing a marketing strategy" (Jackson and Sanyal). Entrepreneurs can be found in Nigerian trading networks, in innovative Peruvian cheese cooperatives, among American university 
students, within Black communities in the U.S., in West Bengali femaleheaded households, and among Brazilian managers, suppliers, LAN House workers and customers. We also learn that entrepreneurship has a long history in at least two of those regions of the world (Onomake-McShane; Bolton et al.), so much so that it is deeply embedded within the culture. The types of people and range of geographic locations suggests a phenomenon that is neither specific nor local, but rather general and global.

Second, the articles identify a range of motivating factors behind the entrepreneurial behavior encountered: making a living (Onomake-McShane), improving a community's livelihood (Bolton et al.), developing a university education with entrepreneurship at its core (Rencher), supplementing household income (Jackson and Sanyal), staving off destitution (Sanyal), and coping with the poor functionality of a product (Erickson). Even when profitability is a goal, it coexists with other equally important or more important goals. For example, recommendations were offered by outside experts to improve the cheese factory's operations, and hence production and revenue (Bolton et al.). One of them-hiring a permanent workforce-was rejected by the community because its "democratic and egalitarian ideal insists on broad participation in the enterprise by all members" and because there are few alternative sources of work for community members.

Third, cultural impact is specific to the particular context. Culture affects the ways in which interactions and relationships transpire in entrepreneurial ventures. Some entrepreneurs/small business owners find they must learn to operate in a cross-cultural context, learning new cultural rules and adapting to unanticipated circumstances (OnomakeMcShane; Jackson and Sanyal). As LAN House employees expand their services, they have to deal with customers whose familiarity with electronics varies widely, and along with it, their varying levels of frustration (Erickson). Other entrepreneurs opt not to adapt but to demand change, as in the Peruvian example when the community shifted from communally-held to individually-held land (Bolton et al.). Students training to become U.S.-based entrepreneurs must acquire entrepreneurial knowledge, skills and practices (i.e., acculturate) so that they can act appropriately in American business circles (Rencher). West Bengali women have to disregard cultural norms to learn about and access self-help groups offering microcredit (Sanyal). In all six articles, the surrounding culture both constrains and enables study participant responses. In other words, a practice that works effectively in one context, may fail miserably in another. Ethnographic and qualitative approaches are adept at describing such situations and offering explanations for their outcomes. 


\section{The Value in Understanding Entrepreneurial Behavior in Context}

The kinds of studies represented in these themed articles make important contributions to our understanding of entrepreneurship and small business activity. They provide a strong dose of "reality" as it is experienced by study participants in "real time," often in their own words and actions. Such studies represent "actual" circumstances faced by people as they navigate an uncertain future. Gillen (2016: 2) makes a similar case: "Knowledge sharing, collaboration, reciprocity, and the role of hometown, locality, and kinship in economic relationships are among many cultural or extra-economic characteristics of entrepreneurialism yet are rarely documented in the existing literature and are thus often illdefined and poorly understood."

These six contextual accounts can and should provide feedback loops into multiple literatures-those concerned with entrepreneurial topics, issues, and interests. Unfortunately, we often find our research does not successfully penetrate the disciplinary silos in which we work. For that reason, venues such as the 2017 Princeton-Kauffman Conference and journals that actively seek and solicit articles beyond their disciplinary borders, such as the Journal of Business Anthropology, are so valuable. They enable interactions that might never have occurred and invite discussion on different perspectives and approaches to a given domain, all with the purpose of expanding mindsets and developing new research practices and opportunities-not to mention, solutions!

\section{References}

Adler, P. A., and P. Adler. 1987. Membership Roles in Field Research. Newbury Park, CA: Sage. https://doi.org/10.4135/9781412984973

Anderson, L. 2006. Analytic Autoethnography, Journal of Contemporary Ethnography 35(4): 373-395. https://doi.org/10.1177/0891241605280449

Atkinson, P. 2006. Rescuing Autoethnography, Journal of Contemporary Ethnography 35(4): 400-404. https://doi.org/10.1177/0891241606286980

Bernard, H. R., A. Wutich, and G.W. Ryan. 2017. Analyzing Qualitative Data. $2^{\text {nd }}$ ed. Thousand Oaks, CA: Sage Publications.

Blim, M. 1990. Made in Italy: Small-scale Industrialization and its Consequences. New York, NY: Praeger.

Brettell, C. B. 2009. Anthropology, Migration, and Comparative Consciousness, New Literary History 40(3): 649-671.

https://doi.org/10.1353/nlh.0.0107 
Briody, E. K., Trotter, R. T. II, and Meerwarth, T. L. 2010. Transforming Culture: Creating and Sustaining a Better Manufacturing Organization. New York, NY: Palgrave Macmillan.

Caulkins, D.D., and C. Peters. 2002. Grid-group Analysis, Social Capital, and Entrepreneurship among North American Ethnic Groups, Cross-Cultural Research 36(1): 48-72. https://doi.org/10.1177/1069397102036001003

Chapple, E.D., and L.R. Sayles. 1961. The Measure of Management: Designing Organizations for Human Effectiveness. New York, NY: Macmillan.

Ellis, C.E., and A.P. Bochner. 2006. Analyzing Analytic Ethnography: An Autopsy, Journal of Contemporary Ethnography 35(4): 429-449. https://doi.org/10.1177/0891241606286979

Ember, C.R., and M. Ember. 2009. Cross-cultural Research Methods. $2^{\text {nd }}$ Ed. Lanham, MD: Altamira.

Feldman, M.S., J. Bell, and M.T. Berger. 2003. Gaining Access: A Practical and Theoretical Guide for Qualitative Researchers. Walnut Creek, CA: AltaMira Press.

Gillen, J. 2016. Entrepreneurialism and Tourism in Contemporary Vietnam. Lanham, MD: Lexington Books.

Golden, B.R. 1992. The Past Is the Past - Or Is It? The Use of Retrospective Accounts as Indicators of Past Strategy, Academy of Management Journal 35(4): 848-860. https://doi.org/10.5465/256318

Hayano, D. 1979. Auto-ethnography: Paradigms, Problems, and Prospects, Human Organization 38(1): 99-104.

https://doi.org/10.17730/humo.38.1.u761n5601t4g318v

https://www.princetonkauffman2017.com

Jordan, A.T., and D.D. Caulkins. 2013. Expanding the Field of Organizational Ethnography for the Twenty-first Century.' In D.D. Caulkins and A.T. Jordan (Eds.) A Companion to Organizational Ethnography, 1-23. Malden, MA: Wiley-Blackwell. https://doi.org/10.1002/9781118325513.ch

Kondo, D.K. 1990. Crafting Selves: Power, Gender, and Discourses of Identity in a Japanese Workplace. Chicago, IL: University of Chicago Press. https://doi.org/10.7208/chicago/9780226098159.001.0001

Learned, K.E. 1992. What Happened Before the Organization? A Model of Organizational Formation, Entrepreneurship Theory \& Practice 17(1): 3948. https://doi.org/10.1177/104225879201700105

Learned, K.E. 1995. The Creation of Firm Resources: A Native Ethnography. Unpublished doctoral dissertation, Lubbock, TX: Texas Tech University.

Lidow, D. 2017. An Urgent Need for More Ethnographic Study of Business 
Creation, Journal of Business Anthropology 6(2): 127-132, Autumn. https://doi.org/10.22439/jba.v6i2.5408

Lusk, J., and K. Harrison. 2002. The Mousedriver Chronicles: The True-life Adventures of Two First-time Entrepreneurs. New York, NY: Basic Books. Marcus, G.E., and P.D. Hall. 1992. Lives in Trust: The Fortunes of Dynastic Families in Late Twentieth-Century America. Boulder, CO: Westview.

Meisch, L.A. 2002. Andean Entrepreneurs: Otavalo Merchants and Musicians in the Global Arena. Austin, TX: University of Texas Press.

Oxfeld, E. 1993. Blood, Sweat and Mah-Jong: Family and Enterprise in an Overseas Chinese Community. Ithaca, NY: Cornell University Press.

Rencher, M. 2012. Crossing the Valley of Death: A Multi-sited, Multi-level Ethnographic Study of Growth Startups and Entrepreneurial Communities in Post-Industrial Detroit. Unpublished Ph.D. dissertation, Detroit, MI: Wayne State University.

Riles, A. 2011. Collateral Knowledge: Legal Reasoning in the Global Financial Markets. Chicago, IL: University of Chicago Press. https://doi.org/10.7208/chicago/9780226719344.001.0001

Rosa, P., and D.D. Caulkins. 2013. Entrepreneurship Studies. In D.D. Caulkins and A.T. Jordan (Eds.) A Companion to Organizational Anthropology, 98-121. Malden, MA: Wiley-Blackwell. https://doi.org/10.1002/9781118325513.ch4

Skinner, J. (Ed.). 2012. The Interview: An Ethnographic Approach. London, UK: Berg.

Smith, V. 2001. Ethnographies of Work and the Work of Ethnographers. In P. Atkinson, A. Coffey, S. Delamont, J. Lofland and L. Lofland (Eds.) Handbook of Ethnography, pp. 220-233. London, UK: Sage Publications.

Spradley, J.P. 2016 (originally 1979). The Ethnographic Interview. Long Grove, IL: Waveland Press.

Stewart, A. 1990. The Bigman Metaphor for Entrepreneurship: A “Library Tale" with Morals on Alternatives for Further Research, Organization Science 1(2): 143-159. https://doi.org/10.1287/orsc.1.2.143

Stewart. A. 1991. A Prospectus on the Anthropology of Entrepreneurship, Entrepreneurship Theory and Practice, 16(2): 71-91. https://doi.org/10.1177/104225879201600206

Stewart, A. 1998. The Ethnographer's Method. Newbury Park, CA: Sage Publications.

Stewart, A. 2003. Help One Another, Use One Another: Toward an Anthropology of Family Business, Entrepreneurship Theory and Practice 27(4): 383-396. https://doi.org/10.1111/1540-8520.00016

Stewart, A. 2014. The Anthropology of Family Business: An Imagined 
Ideal.' In L. Melin, M. Nordqvist, and P. Sharma (Eds.), SAGE Handbook of Family Business, pp. 66-82. Newbury Park, CA: Sage. https://doi.org/10.4135/9781446247556.n4

Stewart, A., and H.E. Aldrich. 2015. Collaboration Between Management and Anthropology Researchers: Obstacles and Opportunities, Academy of Management Perspectives 29(2): 173-192. https://doi.org/10.5465/amp.2013.0161

Strathern, M. 2012. Epilogue: Expectations, Auto-narrative and Beyond, In J. Skinner (Ed.) The Interview: An Ethnographic Approach, pp. 261-266. London, UK: Berg.

Wright, S. 1994. Culture in Anthropology and Organizational Studies, In S. Wright (Eds.) Anthropology of Organizations, pp. 1-31. London, UK: Routledge.

Yanagisako, S.J. 2002. Producing Culture and Capital: Family Firms in Italy. Princeton, NJ: Princeton University Press.

Elizabeth K. Briody, Ph.D., a business anthropologist, has been involved in cultural-change efforts for over 30 years - first at General Motors Research and later through her own consulting practice, Cultural Keys. Recent clients are in petrochemicals, aerospace, health care, consumer products, the U.S. military, and service industries. She is Co-PI on a five-year National Science Foundation grant at Purdue University to "revolutionize" the culture of mechanical engineering. Recent books include Cultural Change from a Business Anthropology Perspective, The Cultural Dimension of Global Business, $8^{\text {th }}$ ed., and the award-winning Transforming Culture.

Alex Stewart, Ph.D., is Professor of Business Administration and Chair in Entrepreneurship in Memorial University of Newfoundland. He received his Ph.D. in Political Science and Social Anthropology, his MBA, and his MA in Social Anthropology from York University in Toronto. His writings are in the areas of business anthropology, ethnography, entrepreneurship, and the sociology of knowledge. He is a past Chair of the Entrepreneurship Division of the Academy of Management and of the Family Enterprise Research Conference, and Co-Chair of the Organization Science Winter Conference. 


\section{Appendix A: Doctoral Dissertations with Ethnography and Entrepreneurship in the Abstract}

These are 100 recent doctoral dissertations with "entrepreneur* OR "new venture*" AND ethnograph* in the abstract, from ProQuest Dissertations and Theses (omitting doctors of education but not Ph.D.'s in education and omitting autho-ethnographies, as of early July 2018). Dissertations are categorized by the main unit(s) of observation. Categories are broad. For example, "sectoral" is meant to include industry, "field" or "arena" of social action. An "ecosystem" would be classed this way. The classification "common activities" encompasses what could be called social institutions. "Topical" ethnography is often "multi-sited." Relatively few studies, those which are underlined, examine new ventures from nearly the start. Only three of the 100 are so categorized.

Lee, Seung-Cheol. 2018. Columbia University, Anthropology. "ethnographic research on the social economy sector" - common activities and self-defined as sector (used to include industries and sets thereof).

Schmidt, Eric James. 2018, UCLA, Ethnomusicology. On "Tuareg music" ethnically defined set of common activities or "art world" and sectoral.

Nichols, T. Philip. 2018. Pennsylvania, Education. A new high school organizational (used to include network forms as well as more corporate forms).

Trent, Tiffany. 2018. Arizona State, Theatre. Ten youth performing arts spaces - organizational.

Melnick, Amiel Bize. 2018. Columbia University, Anthropology. Roadside businesses - sectoral (a term used here for to encompass also fields or arenas; socially recognized and spatial loci of action).

Steiner, Robin. 2018. Arizona, Anthropology. “Oman's citizen labor industry" - sectoral.

Loughlin, Corrina. 2018. Pennsylvania, Communication. "the American evangelical subculture... Life.Church in Edmund Oklahoma... [and] religious entrepreneurs" - organizational and common activities.

Crowell, Jessica Kathleen. 2018. Rutgers, Library Science (apparently). "Philadelphia's KEYSPOT project, a network of digital access and skills programs" - organizational.

Saavedra Espinoza, Mariana. 2017. Cornell, Anthropology. "Colombian business-owning families" - common activities.

Tompkins, Christien Philmarc. 2017. Chicago. Anthropology. New Orleans charter schools. organizational.

Laurencin, Edith. 2017. Rutgers, Anthropology. "small-scale farmers on St. 
Croix U.S. Virgin Islands" - sectoral.

Kim, Esther Grace. 2017. California - Berkeley, Environmental Science, Policy, and Management. "urban sustainability and environmental justice (EJ) in Los Angeles... focus[ing] on one particular sustainability project" sectoral and organizational.

Kyser, Diana C. 2017. Temple, Business. "four small firms from multiple industries" - organizational.

Fouts, Sarah. 2017. Tulane, Latin American Studies. "undocumented food vendors... from Honduras to New Orleans" - sectoral.

Medford, Marcelle Mandisa. 2017. Chicago, Sociology. "Jamaican immigrant cultural organizations" - organizational.

Carfagna, Lindsey B. 2017. Boston College, Sociology. "open learning from the vantage point of learners" - thematic and common activities.

Porter, Amy Lynn. 2017. Wisconsin-Madison, Educational Policy Studies. "youth... in entrepreneurial training programs...and beyond" - common activities.

Weiner, Talia Rose. 2017. Chicago, Comparative Human Development. "a psychoanalytic training institute" - organizational.

Bunting-Hudson, Laura L. 2017. Columbia, Teachers College. "The rap music industry in Bogota, Colombia" - an art world, common activities and sectoral.

Bandinelli, Carolina. 2017. Goldsmith's College, London, Cultural Studies. "young social entrepreneurs in London and Milan" - common activities and sectoral.

Kennedy, John. 2017. Birmingham, Modern Languages. "three small Siberian enterprises" - organizational.

Sischarenco, Elena. 2017. St. Andrews, Anthropology. "entrepreneurs of the construction business in Lombardy" - sectoral.

Bunsit, Thanawit. 2017. Bath, Economics. "borrowers of microfinance" common activities.

De Avillez, Maria Margarida Durão. 2017. Nottingham, Business. Social entrepreneurship in Mozambique - thematic and sectoral.

De Lisio, Ester Elizabeth Amanda. 2016. Toronto, Anthropology. "women involved in sexual commerce in Rio de Janeiro" - common activities and sectoral.

Wang, Carol Kai-Ju. 2016. The New School, Anthropology. AIDS activism common activities.

Ziemer, Jordan Allen. 2016. Texas A\&M, Communication. "evangelical Christian church planters [founders]" - common activities and sectoral. 
Gaultieri, Anthony Angelo. 2016. American, Anthropology. Communities in Washington, D.C. and "the redevelopment of Anacostia Historical District, the Barry Farm public housing project and St. Elizabeth Hospital" - sectoral and organizational.

Khare, Amy Turnbull. 2016. Chicago, Social Service Administration. "public housing redevelopment" - sectoral and thematic.

Lynn, Randy. 2016. George Mason, Sociology. "two suburban high schools" - organizational.

Toombs, Austin Lewis. 2016. Indiana, Informatics and Computing. "a hackerspace...[and] the broader hackerspace movement" organizational and common activities.

Mitts, Leslie Broudo. 2016. Pennsylvania, Anthropology. "entrepreneurs building scalable new ventures"... "global incubators and accelerators" organizational and new ventures.

Williams, Samuel Joseph. 2016. Princeton, Anthropology. "two marketplaces in Istanbul...focusing on the souvenir business of an Alevi Khurdish family and a partnership between two gay nightlife entrepreneurs" - organizational and sectoral.

Bhandari, Riddhi. 2016. American, Anthropology. "local entrepreneurs... in Agra's local tourism market" - sectoral and individual.

Cummins, E. R. 2016. Northeastern, Sociology. Redevelopment and three "sites" of urban planning in Detroit - sectoral and organizational.

Steffen, Megan Amanda. 2016. Princeton, Anthropology. "accelerating social, economic, and geographical shifts" with the study of people of diverse backgrounds, including entrepreneurs - individual and thematic.

Reilly, Patrick Michael. 2016. UCLA, Sociology. "artists with[in] cultural production industries... stand-up comedians in Los Angeles" - individual and sectoral.

Kim, Christina Hyun Im. 2016. New School, Anthropology. South Korean entrepreneurs in China near the North Korean border. individual and sectoral.

Morgan, Paul James. 2016. California - Irvine, Sociology. "craftspeople who sell on Etsy.com and/or at Renegrade Craft Fair" - individual and sectoral.

Jasor, Océane. 2016. Florida International, Global and Sociocultural Studies. "Sonke Gender Justice, a transnational entrepreneurship NGO... in Southern Africa" - organizational.

Yezbick, Julia. 2016. Harvard, Anthropology. "the intersecting worlds of art, creative industries, real estate, philanthropy and urban revitalization through the material lens of single family home" - thematic and sectoral. 
Hsieh, I-Yi. 2016. NYU, East Asian Studies. "the reconstruction of urban folk arts as cultural heritage in China. Focusing on two Beijing folklore markets" - common activities and sectoral.

Gupta, Hemangini. 2016. Emory, Women's Studies. "the emergence of a startup economy in... Bangalore... Startup Festivals, incubation labs, investor and networking meetings, entrepreneurial workplaces, and sites of leisure and consumption" - sectoral, thematic, and organizational.

Russum, Jennifer Ann. 2016. Arizona State, English. “women’s sewing practices in the digital age... participating... online" - common activities and sectoral.

Al-Masri, Muzna. 2016. Goldsmith's College, London, Anthropology. "Beirut's Sunni communities, mainly within Nejmeh Sports Club... an 'entrepreneurial elite'” - sectoral and organizational.

Popova, Irina. 2016. Anglia Ruskin, Anthropology. "social venture incubation... on cohort of social entrepreneurs and their ventures from selection to incorporation" - new ventures.

Di Martini Ugolotti, Nicola. 2016. Bath, Education. "young men of migrant origin... practicing capoeira and parkour in Turin's public spaces" common activities and sectoral.

Gümüșay, Ali Aslan. 2016. Oxford, Organizational Behavior (apparently). "the founding process of the first Islamic Bank in Germany" organizational and new ventures. (I have a request to view the document, which is under embargo, to be sure about this.)

Botoeva, Gulzat. 2016. Essex, Sociology. "small-scale illegal production of hashish in a mountainous region of Kyrgzstan" - common activities and sectoral.

Hung, Julia. 2016. LSE, Anthropology. "Agents in rural Bangladesh... smallscale business women" - sectoral.

Kushins, Eric Ross. 2015. Rutgers, Sociology and Organizational Management. Four small firms- organizational.

Orrico, Laura Ann. 2015. UCLA, Sociology. "a public marketplace [and] a group of marginalized entrepreneurs” - sectoral.

Jones, Anika Yetunde. 2015. Wisconsin - Milwaukee, Anthropology. "African-American women [who become] micro-enterprising entrepreneurs" as child care providers - sectoral.

Jiao, Yang. 2015. Florida, Anthropology. "Chinese entrepreneurs in Ghana... [multiple] sectors [of an] ethnic enclave" - sectoral (the enclave).

Ferguson, Rachael H. 2015. Princeton, Sociology. "actors involved in the extralegal economy... drug entrepreneurs, sexworkers, and members and associates of Mafia groups" - individual and common activities. 
Garrison, Shea Bradley. 2015. Tulane, International Development. "the demand and supply of female labor in Kuwait" - thematic and sectoral.

Hodges, Rebecca McLain. 2015. Washington University, Anthropology. "teachers at a typical Jordanian public school" - individual and organizational.

Taylor, Christopher Brennan. 2015. Boston University, Anthropology. "the rise and transformation of... Islamic almsgiving (zakat)... in contemporary India" - thematic and common activities.

Ignatova, Jacqueline Alyce. 2015. Maryland, Government and Politics. a "new Green Revolution" in Ghana - thematic and sectoral.

Hobden, Deborah. 2015. California - Santa Barbara, Sociology. "Ghana’s first 'world-class' shopping mall” - organizational.

Long, Ziyu. 2015. Purdue, Communication. "women entrepreneurs from three different political-economic systems communicatively design their entrepreneurial careers" - thematic and individual.

Alexander, James. 2015. Manchester, Politics. "how technological security solutions are deployed in everyday life... [and examines] trade fairs and exhibitions where one can witness the marketing and sale of the 'latest and greatest' technological fixes... from private sector security entrepreneurs" but focuses on the "mind-set regarding what it means to consumer security" - thematic and sectoral.

Feldman, Elana. 2015. Boston University, Business. “a seed accelerator ('InnoTech')" - organizational and individual (with respect to the organization).

Akinyemi, Florence Oluwabunmi. 2015. UCLA, Political Science. "peace entrepreneurs" in Yoruba areas of Nigeria who "identify potential conflict situations before they escalate" - common activities and individual.

Jankauskas, Jennifer Kathleen. Leicester, Museum Studies. "mid-sized and regional American art museums" and various art world participants sectoral.

Heslop, Luke Alexander. 2015. Edinburgh, Social Anthropology. "middlemen and business families in a commercial town in central Sri Lanka... in the households of business families, at work in the vegetable market, and at social and political gatherings" (subtitle "A small town ethnography") - sectoral.

Fox, Dierdre. 2015. Ulster, n/a. "twelve entrepreneurial cases engaged in business venturing within traditional textiles, seafood, seaweed processing and cultural tourism"; on "the role of social and cultural capital in Gaeltacht entrepreneurship" - thematic and sectoral.

Erdélyi, Peter. 2015. LSE, Management. "e-commerce and small retailers in the South of England" - sectoral and common activities. 
Mbwilo, Loy Job. 2015. Hull, Business. "Tanzanian rural women entrepreneurs" - individual and common activities.

Dobson, Johnl 2015. Manchester, Business. On "the role [that] institutions play in the adoption and non-adoption of Information Systems... within the Taxco Silver Handicraft Sector" - sectoral and thematic.

Abid, Sufyan. 2015. Sussex, Anthropology. "Muslim businessmen and entrepreneurs in Birmgingham, UK" with a focus on "charity and philanthropy" - individual and common activities.

Chang, Janny. 2014. Columbia, n/a (eclectic references). "workplace relationships among Chinese and Zambians working together... in two urban areas in Zambia [using] three case studies [that involve] Chinese and Zambian entrepreneurial ventures" - sectoral and common activities.

Azcarate, Tania Arriaga. 2014. Nevada, Basque Studies. "a self-branded entrepreneur's innovation community of practice, known as \#NASF... [a] Navarrese community of entrepreneurs" - sectoral and organizational.

Enriquez, Falina. 2014. Chicago, Anthropology. "the primarily statesponsored music scene in Recice," Brazil - sectoral.

Sheth, Anup Arvind. 2014. UCLA, Sociology. "ethnic place naming in Los Angeles;" informants include "ethnic entrepreneurs" (i.e. entrepreneurs regarding ethnicity) - sectoral and common activities.

Roti, Maria R. (2014). Wayne State, Anthropology. "the Russian informal economy [and a] Russian business organization" - sectoral and organizational.

Wood, Mark Williams. 2014. Arizona State, School of Human Evolution and Social Change. "a network of social business incubators operated by Tecnologico de Monterrey... centering on its campus in Guadalajara [studying] if and how [middle and base of the pyramid] businesses address sustainability" - thematic and organizational.

Muse-Orlinoff, Leah. 2014. California - San Diego, Sociology. "pioneer entrepreneurs from a first-generation, low-resource immigrant community... a 'life-cycle' of immigration, settlement, labor market incorporation, and entrepreneurship" - thematic and sectoral.

Pluim, Gary W. J. 2014. Toronto, Curriculum, Teaching and Learning. "youth participation... during an internationally dominated reconstruction of Haiti following the earthquate of 2010" - common activities and sectoral.

Lopez, Marianne Hamilton. 2014. Maryland - Baltimore County, Public Policy. examines "welfare discourse to analyze how the policy community viewed the role of TANF [Temporary Assistance for Needy Families] within [a] deep recession" - thematic and sectoral. 
Keleş, Fethi. 2014. Syracuse, Anthropology. "the resettlement experiences of Bosnian Muslims relocated to two urban locales in the north of New York state" - thematic and sectoral.

Demuynck, Erin. 2014. Illinois, Geography. "farmers markets [and] their compatibility with and incorporation into the entrepreneurial strategies through which cities strive to be competitive" - thematic and sectoral.

Goldstein, Jesse. 2014. CUNY, Sociology. "whether and how 'green capitalism' coheres around new justificatory frames... This research focuses specifically upon individuals within the broad field of green capitalism" - thematic.

Gist, Angela N. 2014. Missouri, Communication. Studies "unemployment support organizations across class lines" - organizational.

Williams, Adam S. 2014. Colorado, Geography. Informal recycling networks and their participants in Shanghai - sectoral.

Davies, Gillian Louise. 2014. Edinburgh, African Studies. Studies "inside two development intermediaries, Global Village Energy Partnership (GVEP) International's 'Developing Energy Enterprises Project' (DEEP) in Kenya and Uganda and SolarAid's social enterprise 'SunnyMoney' in Malawi... [and] the recruitment and training of supply chain entrepreneurs" - sectoral and organizational.

Margey, A. 2014. Queen's, Belfast, Higher Education (apparently). On "attitiudes towards entrepreneurship and enterprise education within Northern Ireland's visual arts and theatre sectors" - thematic and sectoral.

White, Joy. 2014. Greenwich, Literature, Language and Theatre. On grime music and "the informal creative economy... in various settings including pirate radio stations, nightclubs and music video shoots" - thematic.

Finney, Angus. 2014. City University, London, Management. "cognitive biases [in] the film industry value chain" - thematic and sectoral.

Salinas Edwards, Michael Antonio. 2014. Manchester, Criminology. "a contemporary British drug market [and] a group of twenty-five friends, termed The Lads" - thematic and individual.

Rosemann, Achim. 2014. Sussex, Anthropology. "the formation and governance of international clinical research collaborations in the field of regenerative stem cell medicine" - thematic and sectoral.

Rogelja, Igor. 2014. School of Oriental and African Studies, London, Political Science. "how creativity is incorporated in urban redevelopment schemes... particularly in marginal urban spaces...[in]m three case cities in Taiwan and China" - thematic.

Klaeger, Gabriel. 2014. School of Oriental and African Studies, London, Anthropology and Sociology. "the everyday lives of the people who dwell, 
work and move alongside the Accra-Kumasi road" in Ghana - sectoral.

Saleh, Elizabeth. 2014. Goldsmith's College, London, Anthropology.

"Lebanese wine producers and their on-going efforts to create and sustain a niche in the international market for their high quality wines" sectoral and common activities.

Li, Boyi. 2014. LSE, Management. "examines the rationale of geographic co-location of entrepreneurs who do business on internet platforms" thematic and sectoral.

Sethna, Zubin. 2014. Stirling, Business. "examines the factors that have shaped entrepreneurial cognition and practice in entrepreneurs from within the world's oldest monotheistic religious community, the Zarathustrian community" - sectoral and thematic.

Nguyen, An Tuan. 2013. Bowling Green, Ethnic Studies. On "new communities of Vietnamese immigrants in the U.S.... [including] entrepreneurial immigrants" - sectoral.

Ghadge, Ravi. 2013. Illinois, Sociology. "urban development [and] multiple stakeholders" in Mumbai and "an entrepreneurial model" of urban development - sectoral and thematic.

Mendoza, Marcos Alexander. 2013. Chicago, Anthropology. On "environmental capitalism in Patagonia." Various actors include "tourism entrepreneurs" - sectoral and thematic.

Irani, Lilly Cristine. 2013. California - Irvine, Information and Computer Science. "examines the politics of design practice in urban India through an ethnography of a Delhi-based design and innovation studio" organizational and thematic.

Jones, Calvert W. 2013. Yale, Political Science. "I study state-initiated social engineering in the United Arab Emirates [whose leaders] are struggling to build more market-friendly, entrepreneurial citizens..." sectoral and thematic. 


\section{Appendix B: Auto-ethnographic Studies}

The search for these dissertations differs from that in Appendix A because "auto-ethnography" or "native ethnography" and variants are substituted. All 13 of these dissertations, which go back in time to 2005, are included.

Wagg, Andrew. 2017. Keele, Social Sciences (General). a partly autoethnographic study of "different entrepreneurs"... "examine[s] the effects of cognitions, motivations, and self-efficacy on organizational change" - individual and thematic.

Fixsen, Alison Marie. 2017. Westminster, Personal and Professional Development in Education. "staff learning and development programs" in a university that promote "self-entrepreneurial activities, self-care, and self-examination" - organizational and common activities.

Dauncey, Alexander James. 2016. Prifysgol Bangor, Natural Resources and Geography. Retrospective study of "policy entrepreneurs" for UK forestry, utilizing "personal autoethnographic witness from a complete member researcher," focusing on "the mindsets and frames of [the earlier] times... [and] powerful institutional inertia" - sectoral and thematic.

Henderson, Nathalie Means. 2015. Missouri - St. Louis, Education. On how "EE [Educational Entrepreneurship] policies harm Black students, families and educators" - sectoral and individual (reflections on personal experience).

Arzberger, Jennifer E. 2015, Denver, Education. "an educator's journey in developing an economically integrated, urban Expeditionary Learning charter school... traversing the years prior to opening the school... [invoking] personal experiences" - new venture, organizational, sectoral (the network of Expeditionary Learning schools); (retrospective, e.g. p. 36).

James, Juli. 2015. Glamorgan, Marketing. within a "high technology based small business," an "autoenthographic narrative... positioned in three phases to show the progression from no formal marketing marketing to administrative marketing methods through to innovative and entrepreneurial marketing strategies and techniques" - organizational and thematic.

Musgrave, George. 2014. East Anglia, Language and Communication Studies. "competition in UK urban music," partly autoethnographic; on "cultural intermediaries" - thematic and sectoral.

Triplett, Indigo Debra. 2014. Benedictine, Values-Based Leadership. On "my journal of leading with bipolar disorder in an entrepreneurial organization" as CEO of an Inc. 500 fastest-growing companies for 2012 and 2013. New ventures and organizational and individual.

Whelan, Timothy Charles. 2011. Surrey, Management. Includes (Chapter 
5) "a longitudinal autoethnography [on] an environment in which poor leader behaviour precipitated poor leader-subordinate relationships and a reduced willingness to implement ideas, whilst good leader behaviour was associated with more positive attitudes by subordinates and a willingness to take risks and implement ideas" - organizational and thematic.

Alexander, Amanda S. 2010. Ohio State, Art Education. "considers the collaborative process developed with the Colors and Creations cooperative of artists in Cajamarca, Peru," including consideration of "entrepreneurs" and "business(wo)men;" "issues [covered include] trust within the group [and] international economic policy issues (dis)serving the development of direct trade with artists" - organizational and thematic.

Malone, Stephen A. 2009. Lancaster, Management. Studies personal business advisors (PBAs) to small firm, drawing in part on autoethnographic consideration of the author's past experience as a PBA. Key concepts include relationship-building and sensemaking - sector and thematic.

Ryan, John Edwin Holston. 2007. Warwick, Management. The author was one of two founders of a "social entrepreneurial new venture;" the study "explores the relationship between the two entrepreneurs. ... their relationships with their network partners [and] their shared missionrelated values" - new ventures, organizational, and thematic.

Karra, Neri. 2005. Cambridge, Management. An auto-ethnographic study of "an international fashion firm that was born global... highlighting the critical role of the domestic and foreign market environment, as well as existing opportunities in the market" - new ventures, organizational and thematic.

Not counted:

Wolfe, Maria Loukianenko. 2008. Iowa State, Rhetoric and Professional Communication. This is depicted as an auto-ethnography, but it is better described as a reflexive ethnography with full membership in the author's past experience, which was not that of the main protagonist. 